\title{
Efek Kombinasi Epidural dan Obat Anti-inflamasi Nonsteroid terhadap Nyeri dan Kadar Prostaglandin
}

\author{
Jeffri Budianto,, ${ }^{1}$ Muh. Ramli Ahmad, ${ }^{1}$ Syafruddin Gaus, ${ }^{1}$ Ilham Jaya Patellongi ${ }^{2}$ \\ ${ }^{1}$ Departemen Ilmu Anestesi, Perawatan Intensif dan Manajemen Nyeri Fakultas Kedokteran \\ Universitas Hasanuddin, ${ }^{2}$ Departemen Ilmu Fisiologi Fakultas Kedokteran Universitas Hasanuddin
}

\begin{abstract}
Abstrak
Kombinasi analgesia epidural (AE) dengan obat anti-inflamasi nonsteroid (OAINS) seperti ketorolak dan parecoxib sebagai analgesia preventif diperlukan untuk mengurangi nyeri pascabedah. Penelitian ini bertujuan mengetahui efek OAINS sebagai analgesia preventif pada pascabedah laparatomi ginekologi berdasar atas perubahan kadar prostaglandin- $\mathrm{E}_{2}\left(\mathrm{PGE}_{2}\right)$ dan intensitas nyeri. Penelitian bersifat eksperimental acak tersamar ganda dengan jumlah sampel 60 pasien. Penelitian dilakukan di RSUP Dr. Wahidin Sudirohusodo Makasar bulan Maret-Juni 2017. status fisik 1 dan 2 menjalani laparatomi ginekologi dengan anestesi epidural. Subjek dibagi 3 kelompok, yaitu ketorolak (K) 0,5 mg/kgBB intravena, parecoxib (P) $40 \mathrm{mg}$ intravena, dan plasebo $(\mathrm{N}) \mathrm{NaCl}$ 0,9\% 2 mL yang diberikan 30 menit sebelum insisi, 8 jam, dan 16 jam pascabedah. Data dianalisis dengan uji one-way ANOVA, uji Exact Fischer, uji Mann-Whitney U pada batas kemaknaan $\alpha=5 \%$. NRS=1 pada kelompok K dan P saat insisi hingga 16 jam pascabedah dan berbeda signifikan $(\mathrm{p}<0,05)$ dengan kelompok $\mathrm{N} ; 15 \%$ mengalami peningkatan intensitas nyeri $(\mathrm{NRS}=2)$ 8 jam pascabedah. Kadar PGE 2 pada plasebo paling tinggi $(439,7 \pm 35,1 ; 481,7 \pm 60,1 ; 565,1 \pm 58,7)$, berbeda signifikan $(\mathrm{p}<0,05)$ dengan parecoxib $(230,7 \pm 19,5 ; 221,4 \pm 16,4 ; 201,1 \pm 18,1)$. Ketorolak berada di antara keduanya. Simpulan, parecoxib dan ketorolak sebagai analgesia preventif yang dikombinasi AE pada pasien bedah laparatomi ginekologi dapat menekan nyeri dan mengurangi produksi PGE $_{2}$. Efek parecoxib lebih kuat daripada ketorolak mengurangi produksi $\mathrm{PGE}_{2}$, tetapi sama kuatnya dalam menekan intensitas nyeri pascabedah laparatomi ginekologi.
\end{abstract}

Kata kunci: Analgesia epidural, ketorolak, laparatomi ginekologi, parecoxib, $\mathrm{PGE}_{2}$

\section{Combination of Epidural and Non Steroid Anti-inflammatory Drugs on Pain and Prostaglandin of Surgical Patient}

\begin{abstract}
Combination of parecoxib and ketorolac as preventive analgesia may enhance epidural analgesia (EA) on post gynecology laparotomy. The purpose of this study is on the preventive analgesia effect of NSAID on $\mathrm{PGE}_{2}$ level and pain on post operative gynecology laparotomy using EA. This was a double-blind randomized experimental study involving sixty physical. This study State 1 and 2 patient whom underwent gynecology surgery with EA. Subjects were divided into 3 groups: group $\mathrm{K}$ received $0.5 \mathrm{mg} / \mathrm{kgBW}$ ketorolac, group P $40 \mathrm{mg}$ parecoxib and group N NaCl $0.9 \% 2$ cc intravenously. Drugs was given 30 minutes before incision, 8 and 16 hours after incision. Pain intensity and $\mathrm{PGE}_{2}$ level were obtained. Data was collected in numeric, mean (SD), then analyzed by using one-way ANOVA test, Fischer's exact test, Mann-Whitney U-test to a 5\% confidence interval. Statistical analysis showed NRS was 1 on all groups at beginning of incision. Eight and 16 hours after incision, NRS of 1 retained in NSAIDs, while NRS increased to 2 in $15 \%$ of $\mathrm{N}$ groups 8 hours after incision. $\mathrm{PGE}_{2}$ level is highest on $\mathrm{N}$ group and significantly difference $(\mathrm{p}<0.05)$ compared to $\mathrm{P}$ group and $\mathrm{K}$ group. In conclusion, combined EA and NSAIDs as preventive analgesia in gynecology laparotomy patients reduce pain and $\mathrm{PGE}_{2}$ level during and after surgery. Parecoxib was more effective compared to ketorolac in reducing $\mathrm{PGE}_{2}$ level, otherwise both have same effectivity in reducing pain intensity.
\end{abstract}

Key words: Analgesia epidural, ketorolac, gynecology laparotomy, parecoxib, $\mathrm{PGE}_{2}$

Korespondensi: Jeffri Budianto, dr., Departemen Ilmu Anestesi, Perawatan Intensif dan Manajemen Nyeri Fakultas Kedokteran Universitas Hasanuddin, Rumah Sakit Umum Pusat DR. Wahidin Sudirohusodo, Jl. Perintis Kemerdekaan KM 11, Tamanlarea, Makasar, 90245 Tlpn (0411) 584675, Faks (0411) s87676, Email b_Jeffri@vahoo.co. id 


\section{Pendahuluan}

Nyeri pascabedah merupakan permasalahan sangat penting pada pasien pascabedah. Nyeri pascabedah akan memengaruhi sistem kardiovaskular, respirasi, dan endokrin yang berhubungan dengan komplikasi pascabedah. Meskipun pengetahuan kita tentang mekanisme nyeri pascabedah sudah mengalami banyak kemajuan, namun pengelolaan nyeri pascabedah belum optimal dan sering terabaikan. Penelitian di Amerika Serikat menunjukkan 80\% pasien mengalami nyeri akut pascabedah. Penelitian lain memperlihatkan bahwa $40 \%$ pasien mengalami nyeri sedang hingga berat selama 24 jam pertama pascaoperasi. Kontrol nyeri pascabedah yang baik menghasilkan tingkat morbiditas dan mortalitas yang lebih rendah, serta waktu rawat inap yang lebih singkat sehingga mengurangi biaya rata-rata perawatan. . $^{1,2,3}$

Pembedahan menimbulkan konsekuensi nyeri yang bersifat bifasik akibat kerusakan jaringan dan respons inflamasi. Pengelolaan nyeri pascabedah akan menjadi optimal jika kedua proses tersebut dapat dihambat. Analgesia preventif yang mencakup terapi analgesia multimodal sebelum dan sesudah pembedahan bertujuan menurunkan nyeri dan mengurangi konsumsi analgesik pascabedah. Penggunaan obat-obat dan teknik anestesi yang bekerja pada proses sensitisasi sentral dan perifer dalam konsep preventive multimodal analgesia menjadi pedoman penanganan nyeri pascabedah saat ini. Penanganan multimodal analgesia dapat dilakukan berdasar atas intensitas nyeri akibat pembedahan yang dibagi berdasar atas derajat ringan, sedang, dan berat. ${ }^{4-8}$

Kombinasi regional analgesia dan obat golongan lain seperti obat anti-inflamasi nonsteroid (OAINS) pada nyeri akut diperlukan untuk mengurangi bahkan menghilangkan nyeri yang timbul. Teknik analgesia epidural merupakan salah satu modalitas penanganan nyeri akut pascabedah yang paling banyak dilakukan. Pada kasus pascabedah laparatomi ginekologi dengan penilaian nyeri berat pascabedah dengan teknik analgesia epidural umum digunakan. Secara umum analgesia epidural memberikan analgesia yang lebih superior dibanding dengan teknik lain disertai keuntungan fisiologis tertentu, yakni mengurangi respons stres neuroendokrin akibat pembedahan. ${ }^{9-11}$

Pembedahan histerektomi merupakan salah satu jenis pembedahan ginekologi yang paling banyak dilakukan dan nyeri pascabedah melibatkan nyeri somatik dan viseral. Pada penanganan nyeri akut pascahisterektomi yang tidak adekuat, 5-30\% pasien mengalami nyeri kronik sampai 1 tahun pascabedah. ${ }^{9}$

Opioid dan OAINS merupakan analgesia yang banyak dipakai dalam menangani nyeri pascabedah. Opioid terbukti sangat efektif dalam menangani nyeri pascabedah, namun penggunaannya dihubungkan dengan beberapa efek samping. OAINS nonselektif seperti ketorolak dapat menyebabkan gangguan gastrointestinal, ginjal, disfungsi trombosit, dan komplikasi perdarahan yang dapat menyebabkan masalah selama pembedahan. OAINS yang menghambat COX-2 secara selektif seperti parecoxib dikembangkan untuk memberikan efek analgesia dan antiinflamasi dengan mempertahankan fungsi proteksi yang dimediasi oleh enzim COX-1. ${ }^{9}$

Mekanisme kerja OAINS adalah dengan menghambat enzim siklo-oksigenase (COX) merupakan enzim yang bertanggung jawab dalam pembentukan prostaglandin (PG). Prostaglandin sebagai respons inflamasi dihasilkan oleh COX-2, sedangkan prostaglandin sebagai respons fisiologis tubuh dikatalisasi pembentukannya oleh COX-1. Peningkatan jumlah prostaglandin akan meningkatkan sensitivitas nosiseptor terhadap bradikinin, histamin dan serotonin, serta terhadap rangsangan mekanik, kimia, dan suhu. Peningkatan jumlah prostaglandin yang sangat banyak di perifer akan menyebabkan perubahan ekspresi gen pada sistem saraf pusat (SSP) yang akan menyebabkan hiperalgesia dan alodinia. ${ }^{10}$

Penelitian ini bertujuan mengetahui kombinasi efek kombinasi epidural dan OAINS sebagai analgesia preventif pada pascabedah 
laparatomi ginekologi berdasar atas perubahan kadar $\mathrm{PGE}_{2}$ dan intensitas nyeri.

\section{Subjek dan Metode}

Penelitian ini merupakan uji klinis rancangan acak lengkap tersamar ganda. Cara pengambilan sampel dilakukan dengan consecutive sampling. Total sampel 60 orang terdiri atas 20 orang per kelompok, dibagi 3 kelompok, yaitu ketorolak (K) 0,5 mg/ $\mathrm{kgBB} /$ i.v., parecoxib (P) $40 \mathrm{mg}$ intravena dan plasebo (N) $\mathrm{NaCl} 0,9 \% 2 \mathrm{~mL}$ obat diberikan 30 menit sebelum insisi, 8 jam, dan 16 jam pascabedah. Kadar $\mathrm{PGE}_{2}$ dan intensitas nyeri dinilai saat awal insisi pembedahan, 8 jam, dan 16 jam sesudah insisi pembedahan. Penilaian nyeri dan pemberian obat dilakukan tidak bersamaan. Data dianalisis dengan uji one-way ANOVA, uji Exact Fischer uji Mann-Whitney U pada batas kemaknaan $\alpha=5 \%$.

Subjek penelitian, yaitu wanita yang menjalani pembedahan laparatomi ginekologi di RSUP Dr. Wahidin Sudirohusodo Makasar pada bulan Maret-Juni 2017 yang memenuhi kriteria inklusi. Kriteria inklusi adalah pasien yang menjalani pembedahan laparatomi ginekologi, setuju dilakukan teknik anestesi dan analgesia epidural, keluarga pasien setuju untuk ikut serta dalam penelitian, ada persetujuan dokter primer yang merawat, status fisik I-II, perempuan, usia 16-65 tahun, indeks massa tubuh (IMT) 18,50-24,99 kg/ $\mathrm{m}^{2}$, tidak menerima terapi obat yang dapat memengaruhi kadar $\mathrm{PGE}_{2}$ minimal dalam 24 jam. Penelitian ini telah disetujui oleh Komite Etik Fakultas Kedokteran Universitas
Hasanuddin dan dibantu oleh Tim acute pain service (APS).

Kriteria eksklusi adalah pasien dengan kontraindikasi tindakan pemasangan kateter epidural, alergi terhadap bahan penelitian, kondisi gangguan medis yang tidak terkontrol, misalnya gangguan fungsi hati, ginjal, koagulasi, serta kardiovaskular, pasien dengan riwayat penggunaan golongan narkotika, kortikosteroid, atau OAINS <24 jam, hemodinamik tidak stabil, sedang menerima transfusi darah, dan perdarahan aktif.

Kriteria pengeluaran apabila selama operasi terjadi efek samping yang hebat, sampel lisis, timbul alergi terhadap alat dan bahan penelitian yang sebelumnya tidak diketahui, pasien atau keluarga pasien mengundurkan diri, anestesi epidural tidak optimal, dibutuhkannya konversi teknik anestesi, terjadi komplikasi pembedahan, dan lama operasi lebih dari 3 jam.

\section{Hasil}

Dari 60 orang pasien yang mengalami pembedahan laparatomi ginekologi dan memenuhi kriteria terbagi dalam 3 kelompok, yaitu kelompok $\mathrm{P}$ (parecoxib), kelompok $\mathrm{K}$ (ketorolak), dan kelompok $\mathrm{N}$ (plasebo) masing-masing 20 orang pasien.

Berdasar atas karakteristik usia, berat badan, dan IMT ketiga kelompok dapat dianggap homogen ( $p>0,05$; Tabel 1). Artinya usia, berat badan, IMT, dan ASA tidak ikut merancu perbedaan intensitas nyeri dan kadar $\mathrm{PGE}_{2}$ serum. Nilai NRS pada ketiga kelompok sama, yaitu bernilai 1 (Tabel 2). Setelah 8 jam

Tabel 1 Karakteristik Sampel

\begin{tabular}{lcccc}
\hline \multirow{2}{*}{ Variabel } & \multicolumn{3}{c}{ Kelompok } & \multirow{2}{*}{$\mathbf{p}$} \\
\cline { 2 - 4 } & $\mathbf{A}$ & $\begin{array}{c}\mathbf{K} \\
(\mathbf{n = 2 0})\end{array}$ & $\begin{array}{c}\mathbf{N} \\
(\mathbf{n = 2 0})\end{array}$ & \\
\hline Usia (tahun) & $41,2(6,8)$ & $43,7(9,4)$ & $45,7(8,8)$ & 0,237 \\
Berat badan $(\mathrm{kg})$ & $53,5(2,5)$ & $55,7(3,5)$ & $54,1(2,9)$ & 0,065 \\
IMT $\left(\mathrm{kg} / \mathrm{m}^{2}\right)$ & $22,19(1,21)$ & $22,96(1,25)$ & $22,64(1,18)$ & 0,146 \\
\hline
\end{tabular}

Keterangan: data disajikan dalam bentuk angka dan dianalisis dengan uji One-Way ANOVA bermakna bila nilai $\mathrm{p}<0,05$ 


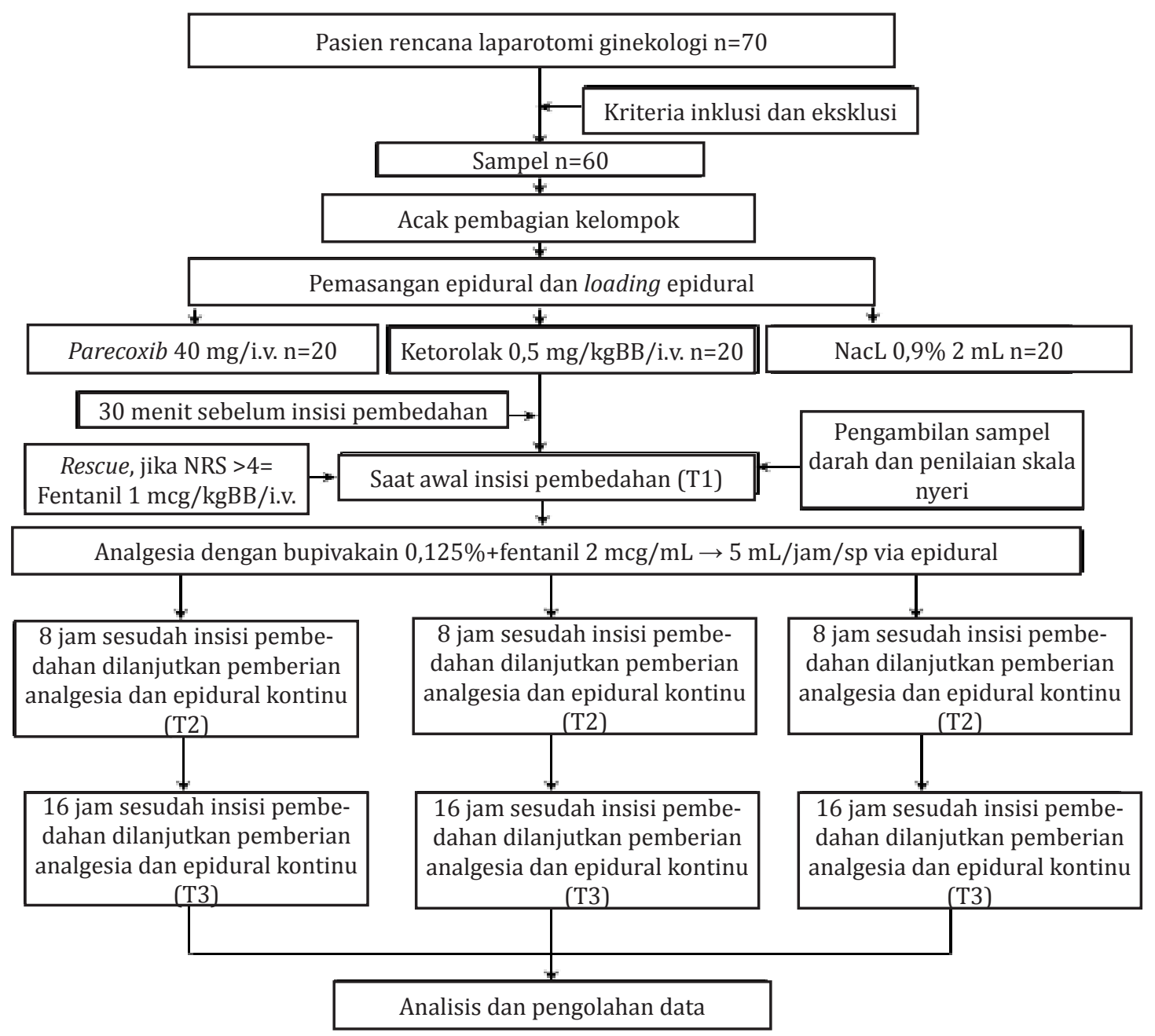

Gambar Alur Penelitian

pertama insisi pembedahan, pada kelompok plasebo ditemukan 3 orang mengalami peningkatan intensitas nyeri dengan NRS 2 , sedangkan pada kedua kelompok lainnya (parecoxib dan ketorolak) tidak mengalami peningkatan NRS sampai 16 jam sesudah insisi pembedahan. Artinya baik parecoxib dan ketorolak efektif menekan intensitas nyeri

\section{Tabel 2 Intensitas Nyeri pada Ketiga Kelompok}

\begin{tabular}{lccccccc}
\hline & kelompok & \multicolumn{2}{c}{ T1 } & \multicolumn{2}{c}{ T2 } & \multicolumn{2}{c}{ T3 } \\
\cline { 2 - 7 } & $\mathbf{n = 2 0 )}$ & NRS=1 & NRS=2 & NRS=1 & NRS=2 & NRS=1 & NRS=2 \\
\hline P & 20 & 0 & 20 & 0 & 20 & 0 \\
K & 20 & 0 & 20 & 0 & 20 & 0 \\
N & 20 & 0 & 17 & 3 & 18 & 2 \\
Total & 60 & 0 & 57 & 3 & 58 & 2 \\
\hline
\end{tabular}

Keterangan: data disajikan dalam bentuk angka dan dianalisis dengan uji deskriptif. $\mathrm{T}_{1}=$ saat insisi pembedahan, $\mathrm{T}_{2}=8$ jam sesudah insisi pembedahan, $\mathrm{T}_{3}=16$ jam sesudah insisi pembedahan 
Tabel 3 Kadar PGE $_{2}$ Serum pada Ketiga Kelompok

\begin{tabular}{lcccccc}
\hline \multirow{2}{*}{$\begin{array}{c}\text { kelompok } \\
(\text { n=20) }\end{array}$} & \multicolumn{2}{c}{ T1 } & \multicolumn{2}{c}{ T2 } & \multicolumn{2}{c}{ T3 } \\
\cline { 2 - 7 } & Mean (SD) & Min./Maks. & Mean (SD) & Min./Maks. & Mean (SD) & Min./Maks. \\
\hline $\mathrm{P}$ & $230,7(19,5)^{*}$ & $187 / 256$ & $221,4(16,4)^{*}$ & $190 / 245$ & $201,1(18,1)^{*}$ & $171 / 231$ \\
$\mathrm{~K}$ & $338,3(22,7)^{*}$ & $298 / 376$ & $360,8(20,2)^{*}$ & $330 / 401$ & $339,6(24,0)^{*}$ & $297 / 387$ \\
$\mathrm{~N}$ & $439,7(35,1)^{*}$ & $345 / 478$ & $481,7(60,1)^{*}$ & $363 / 590$ & $565,1(58,7)^{*}$ & $460 / 719$ \\
\hline
\end{tabular}

Keterangan: data disajikan dalam bentuk mean (SD), dianalisis dengan uji Mann-Whitney U pada setiap kolom dan uji paired T pada setiap baris. ${ }^{\mathrm{p}} \mathrm{p}<0,05$

hingga 16 jam sesudah insisi pembedahan.

Pemberian NSAID (parecoxib dan ketorolak) sebagai analgesia preventif efektif menekan peningkatan produksi $\mathrm{PGE}_{2}$ dan efektivitas parecoxib lebih kuat daripada ketorolak. Kadar $\mathrm{PGE}_{2}$ serum paling tinggi pada kelompok $\mathrm{N}$ saat insisi dan meningkat setelah 8 jam dan terus meningkat setelah 16 jam sesudah insisi pembedahan, sedangkan kadar $\mathrm{PGE}_{2}$ serum pada kelompok $\mathrm{P}$ terendah dan menurun setelah 8 jam insisi pembedahan dan terus menurun setelah 16 jam insisi pembedahan. Kadar $\mathrm{PGE}_{2}$ serum kelompok $\mathrm{K}$ berada di antara kedua kelompok, meningkat setelah 8 jam sesudah insisi pembedahan, dan kemudian kembali sama dengan saat insisi setelah 16 jam (Tabel 3).

Kadar $\mathrm{PGE}_{2}$ serum paling tinggi pada kelompok $\mathrm{N}$ saat insisi dan meningkat setelah 8 jam dan terus meningkat setelah 16 jam insisi pembedahan, sedangkan kadar $\mathrm{PGE}_{2}$ serum pada kelompok $\mathrm{P}$ terendah dan menurun setelah 8 jam insisi pembedahan dan terus menurun setelah 16 jam insisi pembedahan. Kadar $\mathrm{PGE}_{2}$ serum kelompok K berada di antara kedua kelompok, meningkat setelah 8 jam sesudah insisi pembedahan, dan kemudian kembali sama dengan saat insisi setelah 16 jam.

\section{Pembahasan}

Pengelolaan nyeri pascabedah sebaiknya ditujukan ke arah pencegahan atau meminimalkan terjadinya proses sensitisasi perifer dan sentral. Preventif analgesia adalah mencegah nyeri pascabedah. Nyeri kronik yang persisten dapat terjadi pada
10-50\% kasus yang tidak mendapat adekuat analgetik pascabedah. Analgesia preventif ini berdasar atas asumsi bahwa satu-satunya cara untuk mencegah sensitisasi sentral adalah dengan memblokade sinyal nyeri apapun dari luka pembedahan, mulai dari saat insisi hingga penyembuhan luka sempurna. Diharapkan melalui pemberian analgetik secara menyeluruh sebelum nyeri timbul dan pascabedah maka dapat mengurangi intensitas dan durasi nyeri pada nyeri akut pascabedah yang pada akhirnya mencegah nyeri persisten. ${ }^{11}$

Pada penelitian ini, saat awal insisi pembedahan nilai NRS pada ketiga kelompok sama, yaitu bernilai 1 . Setelah 8 jam insisi pembedahan pada kelompok $\mathrm{N}$ ditemukan 3 orang mengalami peningkatan intensitas nyeri dengan NRS 2, sedangkan pada kedua kelompok lainnya (K dan P) tidak mengalami peningkatan NRS sampai 16 jam sesudah insisi pembedahan. Artinya baik parecoxib dan ketorolak, efektif menekan intensitas nyeri hingga 16 jam sesudah insisi pembedahan. ${ }^{1,2}$

Hasil penelitian ini tidak sejalan dengan penelitian lain yang mengungkapkan efek analgesia preventif parecoxib $40 \mathrm{mg}$ intravena lebih baik dibanding dengan ketorolak 0,5 $\mathrm{mg} / \mathrm{kgBB}$ intravena dilihat dari nilai tengah numerical rating scale (NRS) yang lebih. ${ }^{12}$ Pada penelitian ini tidak menggunakan kombinasi analgesia epidural serta AE hanya dapat menghambat jalur neural dan tidak dapat menghambat jalur humoral. Sesuai dengan penelitian membuktikan bahwa epidural preemptif tidak dapat menekan sensitisasi sentral melalui jalur humoral. ${ }^{13}$ 
Hasil penelitian ini juga sesuai seperti yang disimpulkan penelitian lain masing-masing dalam penelitiannya yang mengemukakan bahwa pemberian parecoxib intravena sama efektifnya dengan ketorolak intravena dalam menurunkan nyeri pascabedah. ${ }^{\mathbf{1 4}, 15}$

Pemberian NSAID dapat menekan produksi prostanoid. $\mathrm{PGE}_{2}$ terlibat dalam nyeri dan inflamasi. Prostagladin memediasi sejumlah besar proses di tubuh termasuk inflamasi, nyeri, sekresi pelindung lapisan lambung, mempertahankan perfusi renal, dan agregasi platelet. Prostagladin dengan cepat dimetabolisme, bertindak secara lokal dan terlibat dalam banyak proses yang menyebabkan inflamasi setelah cedera, mengatur kontraksi uterus, memengaruhi vasokonstriksi dan vasodilatasi, serta terlibat dalam agregasi trombosit. ${ }^{15}$

Kadar $\mathrm{PGE}_{2}$ serum saat awal insisi pembedahan paling rendah pada kelompok $\mathrm{P}$ lalu diikuti oleh kelompok $\mathrm{K}$ dan paling tinggi pada kelompok N. Selain itu, pada kelompok N terjadi peningkatan kadar $\mathrm{PGE}_{2}$ serum, 8 jam pertama sesudah insisi pembedahan dan terus meningkat pada 16 jam. Pada kelompok K 8 jam sesudah insisi pembedahan meningkat, tetapi menurun setelah 16 jam. Berbeda dengan parecoxib 8 jam sesudah insisi pembedahan sudah mengalami penurunan dan seterusnya menurun pada 16 jam sesudah insisi pembedahan. Dapat disimpulkan bahwa parecoxib berefek menekan peningkatan inflamasi atau kadar $\mathrm{PGE}_{2}$ serum saat insisi pembedahan dan sampai 16 jam sesudah insisi pembedahan, lebih kuat daripada efek ketorolak.

\section{Simpulan}

Simpulan penelitian ini parecoxib dan ketorolak sebagai analgesia preventif yang dikombinasi $\mathrm{AE}$ pada pasien bedah laparatomi ginekologi dapat menekan nyeri dan mengurangi produksi $\mathrm{PGE}_{2}$ Efek parecoxib lebih kuat daripada ketorolak mengurangi produksi $\mathrm{PGE}_{2}$, tetapi sama kuatnya dalam menekan intensitas nyeri pascabedah laparatomi ginekologi.

\section{Daftar Pustaka}

1. Zeilhofer HU, Brune K. Cyclooxygenase inhibitors: basic aspects. Dalam: Melzack $\mathrm{R}$, penyunting. Wall and Melzack's textbook of pain. Edisi ke-6. Philadelphia: Saunder Elsevier; 2013. hlm. 444-54.

2. Xu LL, Shen JJ, Zhou HY. Effects of parecoxib sodium preemtive analgesia on perioperative cytokine responses and stress responses in patients undergoing opthalmology surgery. Chin J Med Gen. 2010;90(27):1893-6.

3. Siribumrungwong $K$, Cheewakidakam J. Comparison parecoxib and ketorolac as preemptive analgesia in patients undergoing posterior lumbar spinal fusion : a prospective randomized double blinded placebo controlled trial. BMC Musculoskeletal Disorders. 2015;16:59.

4. Samad TA, Sapirstein AA, Woolf CJ. Prostanoid and pain: unrevealing mechanism and revealing therapetic targets. Trens Mol Med 2012;8(8):390-6.

5. Ricciotti E, FitzGerald GA. Prostaglandins and Inflammation. Arteriosler Thromb Vasc Biol. 2011;31(5):986-1000.

6. Hurley RW, Murphy JD. Acute postoperative pain. Dalam: Miller RD, Eriksson L Fleisher L, Wiener-Kronish J, Cohen N, Young W, penyunting. Miller's anesthesia. Edisi ke-8. Philadelphia: Elsevier; 2015. hlm. 2974-98.

7. Buvanendran A, Kroin JS. Multimodal analgesia for controlling acute postoperative pain. Curr Opin Anaesthesiol. 2009;22(5):588-93.

8. Sinatra RS, Jahr JS. Multimodal management of acute pain: the role of iv NSAID. Anesth News. 2011;2011(1):1-8.

9. Brandsborg B, Dueholm M, Jensen TS. Nikolajsen L. Mechanosensitivity before and after hysterecyomy: a prospective study on the prediction of acute and chronic postoperative pain. Br J Anaesth. 2011;107(6):940-7.

10. Morgan GE, Mikhail JR. Regional anesthesia and pain management. Chapter 45-48. Dalam: Morgan GE, Mikhail JR, Butterworth 
JF, Mackey DC, penyunting. Lange-clinical anesthesiology. Edisi ke-5. New York: Lange Medical Books/Mc-Graw-Hill; 2013. hlm. 937-1105.

11. Malhotra N, Singh R, Hooda S, Singla V, Kanika. Intermittent versus continuous epidural infusion technique for post operative analgesia. Northern J ISA. 2016;1(1):24-8.

12. Halim DN. Perbandingan efek antara ketorolak dengan parecoxib sebagai analgesia preventif terhadap intensitas nyeri dan kadar prostaglandin pada pasien pascabedah seksio sesarea. Makassar: Universitas Hasanuddin; 2016.

13. Ahmad MR. Peran analgesia epidural preemtif terhadap intensitas nyeri, respon hemodinamik serta dinamika kadar sitokin proinflamasi dan antiinflamasi pada pasca bedah ekstremitas bawah. (Disertasi Doktoral). Makassar: Universitas Hasanuddin; 2012.

14. Vadivelu N, Mitra S, Narayan D. Recent advances in postoperative pain management. Yale J Biol Med. 2010; 83:11-25.

15. Leykin Y, Casati A. A prospective, randomized, double-blind comparison between parecoxib and ketorolac for early postoperative analgesia following nasal surgery. Minerva Anestesiologica 2008; 74:475-9. 